\author{
Jacek Strojny \\ University of Agriculture in Krakow \\ e-mail: rrstrojn@cyf-kr.edu.pl \\ ORCID: 0000-0002-0577-377X
}

\title{
AGRI-FOOD EXPORTS AND AGRICULTURAL OUTPUT IN SELECTED EU MEMBER STATES
}

\author{
DOI: $10.15611 / \mathrm{pn} .2021 .1 .10$ \\ JEL Classification: C32, C39, N50, Q17 \\ (C) 2021 Jacek Strojny \\ This work is licensed under the Creative Commons Attribution-ShareAlike 4.0 International \\ License. To view a copy of this license, visit http://creativecommons.org/licenses/by-sa/4.0/ \\ Quote as: Strojny, J. (2020). Agri-food exports and agricultural output in selected EU member \\ states. Prace Naukowe Uniwersytetu Ekonomicznego we Wroctawiu, 64(7).
}

\begin{abstract}
This sectoral study of the largest food exporters in the EU focuses on the impact of foreign trade in products made from agricultural commodities on the prospects of agricultural output development. In particular, the study analyses the interdependencies between the output and exports of selected goods. The methodology of vector autoregression was applied to describe the analysed relationships. The results of analyses support the hypothesis about the stimulating role of exports for output and, in the case of certain countries, identify the opposite direction of the causal relationship. The impact of exports on agricultural output is of a short-term nature. Exports appear to be more exogenous than output. The degree of exogeneity of agri-food exports is lowest in the Netherlands.
\end{abstract}

Keywords: agricultural production, agri-food trade, VAR models, cointegration analysis

\section{Introduction}

Technological development in advanced economies has led to a more rapid increase in agricultural production than growth in domestic demand. Domestic demand is income inelastic, with the tendency for agriculture to oversupply the market. However, resources in agriculture are only grudgingly transferrable to other sectors of the economy (Bowler, 2014). Generally, small farms have lesser flexibility over the substitutability of one factor of production. This inertia is reflected in their inefficient use to some extent in the agricultural sector. Increased productivity and efficiency in the industry, combined with the protection producers from the full rigors of the market has led to the formation of structural surpluses. Foreign markets 
have enabled suppliers to overcome the limitations of the domestic market in reaping the advantages of economies of scale (Cherunilam, 2008).

The development of exports should be perceived in normative terms as one of the aspects of economic policy which is aimed at achieving growth objectives in certain areas of economic activity. An alternative, narrow approach is to treat the export-oriented policy as an area of foreign trade, a manifestation of trade policy. The export development strategy should be classified in terms of economic policy rather than in terms of trade policy due to the potential to accelerate economic growth, which cannot be achieved otherwise (Rynarzewski, and Zielińska-Głębocka, 2006). Therefore, export development should not be considered as an objective in itself, but rather as a method of the acceleration of economic growth.

An export-oriented policy focusing on selected sectors may become a factor accelerating economic development with an effect comparable to traditional growth factors such as labour, capital or broadly understood resources. Theoretical studies have proved that the spillover effects of growth impulse for industries not directly participating in the export expansion should be perceived as the source of development of the entire economy (Awokuse, 2005; Bosupeng, 2015; Rosati, 1990; Yang, 2008).

Economic literature lists exports as a potential factor in stimulating the economic growth rate. Nevertheless, many papers suggest the opposite direction of the causal relationship - the possibility that exports are boosted by the growing rate of economic growth (Bahmani-Oskooee, and Economidou, 2009; Henriques, and Sadorsky, 1996). Such trends have been observed both for industrial sectors and for the agri-food sector (Strojny, 2020).

The subject matter of the study is indeed related to the effects that can be achieved through some forms of international trade. In particular, the study assesses the impact of foreign trade on economic growth in sectoral terms. The prospects of stimulating the development of the agri-food sector by foreign trade have been assessed for selected EU member states. Therefore, the study analyses the impact of foreign trade in products based on agricultural commodities on the prospects of stimulating agricultural output.

\section{The research and the method}

\subsection{Literature review}

Foreign trade is defined in different ways. The term means the exchange of goods and services where transactions cross the borders of the countries involved in the process. The main forms of foreign trade are exports, imports and transit trade characterised by the specific nature of the transaction (Nowak, and Kozioł, 2011). In Polish literature, Misala (2005) presents a comprehensive assessment of the impact and characteristics of foreign trade channels (both exports and imports) on the development of the national economy. 
The evolution of economic theory has emphasised the efficiency function of international trade. It highlights the problem of the optimal allocation of resources on an international scale as a result of economic exchange. As a result of accurate international specialisation, the efficiency of management is improved (Bossak, and Bieńkowski, 2004). According to Nakonieczna-Kisiel (1996), the achievement of benefits from trade depends on the appropriate specialisation and sufficient output scale.

The directions of the impact of international trade on economic growth such as sectoral economies of scale, the effects of allocation of output factors between sectors, or the reduction of duplication of research activities, were identified by Rivera-Batiz and Romer (1991). Unel (2010) connected economic growth with research on new products and concludes that the impact of trade on growth is only positive. According to Baldwin and Robert-Nicoud (2008), the growth-supporting effect of trade is reflected in the decreasing prices of new technologies.

Gustafsson and Segerstrom (2010) reported the impact of trade on the intra-sectoral reallocation of resources to the most productive enterprises. However, the authors noted that as a result of trade liberalisation, negative effects may prevail if productivity and innovation growth are weakened. Certain studies clearly find no connection between trade development and economic growth. This applies in particular to trade between countries at different levels of development in a liberalised environment (Dinopoulos, and Segerstrom, 2006). According to Feenstra (1996), the opening of the economy accelerates growth in a more competitive country while affecting economic growth in a less efficient country. Grossman and Helpman (1989) noted that in a free trade environment a more developed country reports a higher growth rate. Enterprises from more developed countries introduce innovations, while companies from less developed countries can only imitate. Thus, with a low imitation rate, trade can have a negative impact on the growth rate in such countries.

\subsection{The method and data}

The aim of the study is to identify and assess the nature of relationships between the key aspects of foreign trade in products based on agricultural commodities and the level of agricultural output in selected EU member states. Due to limitations regarding the presentation of the results, this study was limited to countries with the largest agricultural exports and the best balance of trade in this sector in the EU. Therefore the above mentioned correlations were analysed for the Netherlands, Spain, Poland, and France.

The study is based on EUROSTAT data for the period between 2002 and 2019. Information on agricultural output is a category defined as Agricultural output production value at basic price (current million Euro). For international comparability purposes, statistical data on the size of trade flows of products based on agricultural commodities are classified according to Standard International Trade Classification 
(SITC) and represent the SITC 0+1 (Food, drinks and tobacco) class. In this category, the following variables are analysed in terms of value (in million Euro): Exports (Ex), Imports (Im), and Trade balance (Bal). In addition, some models have introduced the zero-one variable Y2009, which adjusts the trade flows for the impact of the 2008 financial crisis. The prefix "d_" before the name of the variable indicates its first differences. The symbol "_1" after the name of the variable refers to the first lags.

The interdependencies between the level of agricultural output and foreign trade in goods produced from agricultural commodities were described using the vector autoregression methodology (Charemza, and Deadman, 1997; Kusideł, 2000; Lütkepohl, 1991). The nature of the relationships between the variables was identified using the Johansen test (Johansen, 1988), which applied vector autoregression models (VAR) transformed into the vector error correction model (VECM). Cointegration analysis consists in identifying $\tilde{\mathbf{O}}$ matrix rank in the Johansen test. The rank of this matrix is equal to the number of independent cointegrating vectors. On this basis, the final form of the model was selected for each country.

VAR models are developed on the basis of stationary variables. This aspect of time series was tested using the KPSS test (Kwiatkowski, Phillips, Schmidt, and Shin, 1992). Non-stationary time series were transformed by differentiation to meet the criterion of stationarity.

The VAR model does not involve the classic division into endogenous and exogenous variables. The hypotheses relating to the nature of relationships between the variables were verified based on causality tests, the analysis of impulse response function $(I R F)$ and the analysis of variance decomposition of forecast error. For the (Granger) causality test, the $F$-test was used. For each variable in the VAR system a Granger causality test was performed in which the null hypothesis assumed that no lags of variable $j$ were significant in the equation for another variable $i$ (Osińska, 2006). The variance decomposition analysis is used to determine the share of the model variables in explaining the studied correlations. Low shares of explanatory variables prove the independence of the response variable in a given model equation in relation to the relevant explanatory variable. The impulse response function analysis $(I R F)$ was used to assess the interactions between the variables over time. The study presents the distribution over time of the reaction of the response variable in the analysed equation to an impulse from the other model variables.

\section{Results and discussion}

Considering the purpose of the study, countries with a foreign trade surplus with regard to goods produced from agricultural commodities are potentially the most interesting. In the EU, in the order reflecting the size of the positive trade balance in 2019, such countries included the Netherlands, Spain, Poland, France, Belgium, 
Denmark, Ireland, Italy, Hungary, Lithuania, Bulgaria, Austria, and Latvia, respectively. In addition, Germany and the United Kingdom are major food exporters (Table 1). Apart from those already listed, important agricultural producers in the EU are also Romania and Greece (Figure 1). Due to limited possibilities of presenting the results of analyses, only countries with the highest trade surplus with regard to agri-food products, such as the Netherlands, Spain, Poland and France, were included in the study (Table 1).

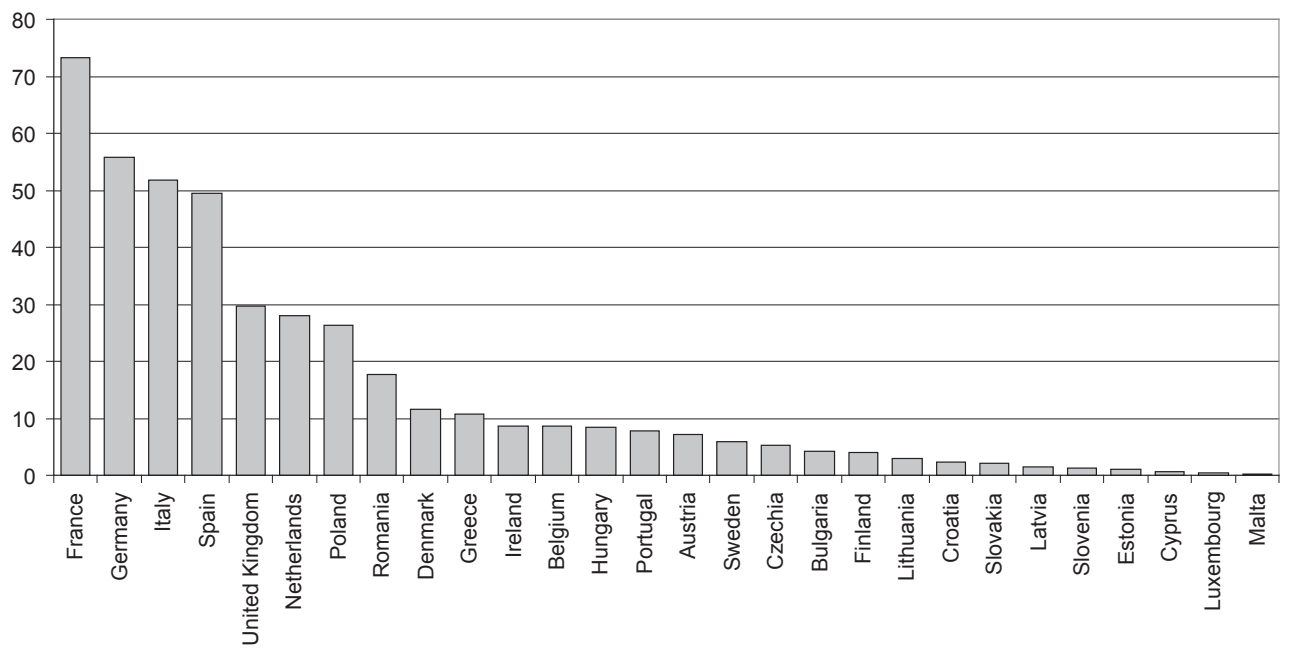

Fig. 1. Agricultural production of EU countries in 2019 (bln Euro)

Source: own calculations based on (Eurostat, n.d.).

The share of the agri-food sector in the respective national economies is reflected in the generated gross value added (GVA). As a rule, this figure is to a certain extent proportional to the size of agricultural production. However, some countries generate an above-average income from agriculture (estimated by the GVA/production ratio provided in brackets next to the country's name). Italy is the most efficient in this respect (0.613). Other countries with efficient agriculture are Spain (0.537), Greece (0.531), Malta (0.517), Romania (0.509), and Cyprus (0.501). Poland reports an average ratio (0.396). Member States with the relatively lowest ratios are Czechia (0.320), Finland (0.312), Denmark (0.305), Luxembourg (0.298), Sweden (0.291), Belgium (0.263), and Slovakia (0.243).

The nature of the relationships between the level of agricultural output and foreign trade in products based on agricultural commodities was estimated using the vector autoregression (VAR) and the vector error correction model (VECM). On the basis of the results of the stationarity test (KPSS) and the Johansen cointegration test, the analysis for Poland did not identify cointegrating vectors for the analysed 
Table 2. Agricultural output and international trade of agri-food products of EU countries in 2019 ( $\mathrm{mln}$ Euro)

\begin{tabular}{|c|c|c|c|c|c|}
\hline \multirow[b]{2}{*}{ Country } & \multicolumn{2}{|c|}{ Agricultural output } & \multicolumn{3}{|c|}{ Food, drinks and tobacco } \\
\hline & production & GVA & exports & imports & $\begin{array}{c}\text { trade } \\
\text { balance }\end{array}$ \\
\hline Austria & 7142.1 & 3307.3 & 12057.6 & 11912.0 & 145.7 \\
\hline Belgium & 8654.2 & 2279.3 & 37444.7 & 30697.4 & 6747.2 \\
\hline Bulgaria & 4151.1 & 1912.6 & 3808.4 & 3178.7 & 629.7 \\
\hline Croatia & 2240.1 & 1067.4 & 2011.6 & 3168.8 & -1157.2 \\
\hline Cyprus & 716.9 & 359.0 & 439.3 & 1173.9 & -734.6 \\
\hline Czechia & 5200.9 & 1661.7 & 6857.1 & 8542.5 & -1685.4 \\
\hline Denmark & 11474.8 & 3499.0 & 17288.1 & 11944.5 & 5343.6 \\
\hline Estonia & 983.6 & 350.6 & 1280.0 & 1531.1 & -251.1 \\
\hline Finland & 4016.3 & 1254.2 & 1666.1 & 4697.7 & -3031.6 \\
\hline France & 73286.4 & 31270.7 & 59632.5 & 51298.0 & 8334.5 \\
\hline Germany & 55843.8 & 21052.3 & 69631.0 & 80492.5 & -10861.5 \\
\hline Greece & 10704.5 & 5689.2 & 5560.6 & 6730.8 & -1170.2 \\
\hline Hungary & 8434.9 & 3498.7 & 7626.7 & 5590.2 & 2036.5 \\
\hline Ireland & 8680.8 & 2917.0 & 13388.8 & 8796.3 & 4592.5 \\
\hline Italy & 51809.0 & 31775.4 & 40860.1 & 38148.7 & 2711.4 \\
\hline Latvia & 1444.7 & 533.5 & 2846.8 & 2744.7 & 102.1 \\
\hline Lithuania & 2940.5 & 1352.7 & 4921.1 & 3671.9 & 1249.2 \\
\hline Luxembourg & 393.7 & 117.4 & 1188.0 & 2409.7 & -1221.7 \\
\hline Malta & 120.6 & 62.3 & 245.1 & 673.0 & -427.8 \\
\hline Netherlands & 27961.4 & 11230.3 & 77199.6 & 52128.6 & 25071.0 \\
\hline Poland & 26301.7 & 10403.1 & 29872.7 & 18550.6 & 11322.1 \\
\hline Portugal & 7746.6 & 3159.3 & 6318.6 & 9729.0 & -3410.4 \\
\hline Romania & 17641.2 & 8980.2 & 5879.4 & 7505.9 & -1626.5 \\
\hline Slovakia & 2081.3 & 506.7 & 2549.4 & 4431.8 & -1882.4 \\
\hline Slovenia & 1336.4 & 578.2 & 2016.0 & 2817.4 & -801.3 \\
\hline Spain & 49451.3 & 26556.0 & 46061.2 & 32666.6 & 13394.6 \\
\hline Sweden & 5791.9 & 1682.6 & 8894.2 & 14718.8 & -5824.6 \\
\hline United Kingdom & 29701.1 & 11673.2 & 27096.9 & 54059.5 & -26962.6 \\
\hline
\end{tabular}

Source: own calculations based on (Eurostat, n.d.).

variables. With the non-stationarity of variables, a cointegration test suggested relying on the VAR model for the variables' first differences. The results of the estimation of the two-equation model describing short-term relationships are presented in Table 2 . 
Table 2. The VAR model for Poland (the variables' first differences)

\begin{tabular}{|l|c|c||c|c|}
\cline { 2 - 5 } \multicolumn{1}{c|}{} & \multicolumn{2}{c|}{ Equation d_P1 } & \multicolumn{2}{c|}{ Equation d_Ex } \\
\hline \multicolumn{1}{c|}{ Model's components } & estimate & $p$ value & estimate & $p$ value \\
\hline const & 3018.190 & 0.001 & 2136.060 & 0.000 \\
\hline d_P1_1 & 0.180 & 0.350 & 0.102 & 0.360 \\
\hline d_Ex_1 & -1.190 & 0.020 & -0.290 & 0.277 \\
\hline Y2009 & -5918.140 & 0.001 & -1998.290 & 0.020 \\
\hline Causality test & $F(1,12)$ & $p$ value & $F(1,12)$ & $p$ value \\
\hline d_P1 & 0.944 & 0.350 & 0.905 & 0.360 \\
\hline d_Ex & 7.260 & 0.019 & 1.299 & 0.276 \\
\hline Variance decomposition & variable's share (last period) & variable's share (last period) \\
\hline d_P1 & \multicolumn{3}{c|}{$68.6 \%$} & \multicolumn{2}{c|}{$3.0 \%$} \\
\hline d_Ex & \multicolumn{3}{c|}{$31.4 \%$} & \multicolumn{2}{c|}{} \\
\hline
\end{tabular}

Source: own calculations based on (Eurostat, n.d.).

The estimated model suggests a statistical significance $(p=0.020)$ of the impact of exports (first lags of the variable d_Ex_1) on agricultural output (d_P1). In the output equation (d_P1), additionally important is the variable adjusting for the impact of the 2008 financial crisis (Y2009). The impact of exports on agricultural output in Poland is confirmed by the result of the causality test $(F=7.260$; $p=0.020)$. The results of the impulse response function (IRF) test suggest the relatively strong effect of exports on output in the first year and its expiration in the second year. The effect derived from output to output is generally also strong only in the first year. Variance decomposition analysis indicates that the lags of first differences in output (d_P1) have a $68.6 \%$ impact on this variable, while the lags of first differences in exports (d_Ex) account for $31.4 \%$ of changes in $\mathrm{d} P 1$.

In the exports equation (d_Ex), none of the system variables are statistically significant. The causality test does not identify any causal relationships for any component of this equation either. The variance decomposition analysis suggests that exports are impacted only by their own lagging values (97.0\%).

The assessment of the nature of interdependencies between French agricultural output and foreign trade in agricultural products was based on the VAR model for variables' levels. The applied form of the model results from the stationarity of variables (KPSS test) and the recommendations of the test for cointegration (total stationarity of variables). The components and estimates of model parameters are presented in Table 3. 
Table 3. The VAR model for France (the variables' levels)

\begin{tabular}{|l|c|c|c|c|}
\cline { 2 - 5 } \multicolumn{1}{c|}{} & \multicolumn{2}{c|}{ Equation P1 } & \multicolumn{2}{c|}{ Equation Ex } \\
\hline Model's components & estimate & $p$ value & estimate & $p$ value \\
\hline const & 52344.800 & $<0.000$ & 16927.300 & 0,026 \\
\hline P1_1 & -0.467 & 0.051 & -0.479 & 0,028 \\
\hline Ex_1 & 0.833 & $<0.000$ & 1.244 & $<0,000$ \\
\hline Y2009 & -2992.640 & 0.011 & -4504.830 & 0,000 \\
\hline Bal & 0.962 & 0.002 & 0.644 & 0,098 \\
\hline Causality test & $F(1,12)$ & $p$ value & $F(1,12)$ & $p$ value \\
\hline P1 & 4.701 & 0.051 & 6.283 & 0,027 \\
\hline Ex & 33.550 & $<0.000$ & 95.482 & 0,000 \\
\hline Variance decomposition & variable's share (last period) & variable's share (last period) \\
\hline P1 & \multicolumn{3}{c|}{$23.4 \%$} & \multicolumn{2}{c|}{$4.4 \%$} \\
\hline Ex $76.4 \%$ & \multicolumn{2}{c}{} \\
\hline
\end{tabular}

Source: own calculations based on (Eurostat, n.d.).

In the output equation (P1), both the VAR system components P1_1 $(p=0.051)$ and Ex_1 $(p<0.000)$, and the exogenous variables Y2009 $(p=0.011)$ and Bal $(p=0.002)$ are statistically significant. The model implies the positive impact of exports and the negative impact of past output values on output. In addition, agricultural output is stimulated by a positive trade balance. The negative impact of the financial crisis (Bal) on the level of output became apparent. The result of the causality test confirms both the impact of exports $(F=33.550 ; p<0.000)$ and the impact of output $(F=4.7014 ; p=0.051)$ on output. The $I R F$ function suggests a monocyclic impact of exports and output on agricultural output in France. The stimulating effect derived from output is 10 times greater in terms of value. However, variance decomposition analysis suggests a $76.4 \%$ share of exports in agricultural output.

In the second equation, all VAR system components and exogenous variables are again significant. The causality test implies the impact of both system variables on exports. The variance decomposition analysis shows that exports are mainly determined by their own trend $(95.6 \%)$. The $I R F$ function analysis completes this picture with a multicyclic trend of fading impulses from system variables - even though the stimulating effect for exports is the strongest in the first year.

The relationships between the agricultural output of the Netherlands and the foreign trade in agri-food products as a result of the recommendations of the test for cointegration were analysed using the VECM model for variables' levels. The model representing long-term relationships consists of constant term (const), time variable (time), the Y2009 variable, and the error correction term (EC1). The estimation of the parameters of the two-equation VECM system is presented in Table 4. 
Table 4. The VECM model for the Netherlands (the variables' levels)

\begin{tabular}{|l|c|c|c|c|}
\cline { 2 - 5 } \multicolumn{1}{c|}{} & \multicolumn{2}{c|}{ Equation d_P1 } & \multicolumn{2}{c|}{ Equation d_Ex } \\
\hline Model's components & estimate & $p$ value & estimate & $p$ value \\
\hline const & 6167.510 & 0.019 & 15700.900 & $<0.000$ \\
\hline Y2009 & -1878.760 & 0.044 & -4123.200 & $<0.000$ \\
\hline time & 830.846 & 0.037 & 2186.000 & $<0.000$ \\
\hline EC1 & 0.326 & 0.033 & 0.820 & $<0.000$ \\
\hline Variance decomposition & variable's share (last period) & variable's share (last period) \\
\hline P1 & \multicolumn{2}{c|}{$85.3 \%$} & \multicolumn{2}{c|}{$80.0 \%$} \\
\hline Ex & \multicolumn{2}{c|}{$14.7 \%$} & \multicolumn{2}{c|}{} \\
\hline
\end{tabular}

Source: own calculations based on (Eurostat, n.d.).

In the output equation (d_P1), all the components of the VECM model are statistically significant. The time variable reflects the positive trend in agricultural output. The Y2009 variable adjusts the drop in output for the impact of the 2008 financial crisis. The EC1 component also has a positive ratio in this equation. The $I R F$ analysis suggests the growing stimulating effect of past output levels on output that is slightly stronger in terms of value than the impact of exports in this respect. The impact of the system variables on output is the strongest in the first year, while after the second year the stimulating effect clearly decreases and stabilises. The variance decomposition analysis indicates that output is mainly determined by its own trend (P1). The impact of exports in this area is estimated at $85.3 \%$.

In the exports equation (d_Ex), all the components of the VECM system are also statistically highly significant $(p<0.000)$. The direction of their impact is consistent with that observed in the output equation, but the strength of their impact is greater. The IRF analysis identifies a decreasing stimulating effect of system variables on exports, which stabilises after the second period. The variance decomposition analysis suggests that $80 \%$ of exports are determined by their own trend and $20 \%$ by past output values.

The relationship between Spain's agricultural output and foreign trade in agri-food products was studied on the basis of the VAR model for the variables' first differences. The selection of the form of the model results from the non-stationarity of the original variables and the recommendations from the test for cointegration. The estimates of the parameters of the two-equation VAR system with the exogenous variable Import (d_Im) are presented in Table 5.

In the output equation (d_P1), both the VAR system variables are generally significant (d_P1 is marginally statistically significant). Historical output values (d_P1) have a destimulating effect on the level of current output, while increases in exports stimulate Spanish agricultural output. Imports also have a stimulating effect on output, which results from a higher growth rate of exports than the rate of output. 
Table 5. The VAR model for Spain (the variables' first differences)

\begin{tabular}{|l|c|c||c|c|}
\cline { 2 - 5 } \multicolumn{1}{c|}{} & \multicolumn{2}{c||}{ Equation d_P1 } & \multicolumn{2}{c|}{ Equation d_Ex } \\
\hline \multicolumn{1}{c|}{ Model's components } & estimate & $p$ value & estimate & $p$ value \\
\hline const & -2477.490 & 0.021 & 646.991 & 0.290 \\
\hline d_P1_1 & -0.456 & 0.058 & -0.088 & 0.529 \\
\hline d_Ex_1 & 1.235 & 0.021 & 0.329 & 0.280 \\
\hline d_Im & 1.435 & 0.002 & 0.577 & 0.030 \\
\hline Causality test & $F(1,12)$ & $p$ value & $F(1,12)$ & $p$ value \\
\hline d_P1 & 4.359 & 0.058 & 0.418 & 0.529 \\
\hline d_Ex & 7.051 & 0.021 & 1.279 & 0.280 \\
\hline Variance decomposition & variable's share (last period) & variable's share (last period) \\
\hline d_P1 & \multicolumn{3}{c|}{$65.3 \%$} & \multicolumn{2}{c|}{$5.3 \%$} \\
\hline d_Ex & \multicolumn{3}{c|}{$34.7 \%$} & \multicolumn{2}{c}{} \\
\hline
\end{tabular}

Source: own calculations based on (Eurostat, 2020).

The result of the causality test confirms the relationship between output and its past values $(F=4.359 ; p=0.058)$ and the level of exports $(F=7.051 ; p=0.021)$. The impulse response function $(I R F)$ indicates the monocyclic impact of the VAR system variables on output. The variance decomposition analysis shows that Spain's agricultural output is mostly determined by its own trend (65.3\%), and $34.7 \%$ by exports.

In the exports equation (d_Ex), none of the VAR system variables are statistically significant. Instead, the exogenous import variable $(p=0.030)$ is significant and shows a positive correlation with exports. The variance decomposition analysis implies that exports are determined by their own trend (94.7\%). On the basis of the $I R F$ function analysis it can be concluded that the lagging values of this variable affect its current values up to two periods back.

The VAR model was applied to describe the analysed interdependencies in the case of Poland, Spain and France. For the Netherlands, the VECM model was applied. The model was selected based on the result of the stationarity test and the recommendation from the test for cointegration. The models for Poland and Spain were based on differentiated variables, and for France on variables in their original (stationary) form. By definition, the VAR models describe short-term relationships and the VECM models describe long-term relationships.

Excluding exogenous components, each model included variables representing the level of agricultural output and exports. In addition, Spain's imports (with a positive impact on output) were also statistically significant. Among the major food exporters in the EU, high levels of output from the past period tend to be destimulating and exports tend to be stimulating for agricultural output. In the Netherlands, the positive 
impact of the output trend was notable. The causality test suggests a significant correlation between exports and output in Poland, Spain and France. In Spain and France, output is also determined by its own trend (marginally statistically significant). On the other hand, the impact of system variables on the level of exports was only identified in the case of France.

The vector autoregression methodology does not require defining the nature of the analysed variables a priori. The study allows the determination of the scope of exogeneity of the system components and the nature of their interdependency. The impulse response function and variance decomposition analysis are useful in this respect. The $I R F$ analysis allows to determine that errors of the model components have a short-term effect on output. This is particularly strong in the first year, and in the second year almost completely expires. In the long-term model (the Netherlands), the effect of system variable errors expires a bit later (after the fourth year), but it is also strong only in the first year. In Poland and the Netherlands the export impulse stimulates agricultural output in the first year after occurrence. In short-term models, historical high output values inhibit output growth in current periods. In the long-term model, all output and export lags have a stimulating effect on dependent variables (output, exports) in respective equations of the system. The effect of the VAR system component errors on exports is also short-lived (one year) in Poland and Spain, which is destimulating. In France this impulse stimulates exports and lasts longer, whereas in the Netherlands the long-term impact on exports expires after the second year and stabilises at a negative value.

Another source of information about the relationships between system variables is the variance decomposition analysis. The study proves the stability of the estimated models. Stabilisation of the shares of variance already occurs from the second up to the fourth forecast period. Agricultural output is the most independent in the Netherlands (85.3\% due to its own trend). In Spain (65.3\%) and Poland (68.6\%), historical output levels have a slightly weaker impact on its current values. In France, output lags affect its current values at $23.4 \%$, with the prevailing share of exports (76.4\%). However, $95 \%$ to $98 \%$ of agri-food exports in Poland, France and Spain are determined by their own trend. The decomposition analysis suggests the low independence of exports in the Netherlands, where agricultural output appears to be more exogenous.

The obtained results seem to be in line with the conclusions of other analyses carried out at macroeconomic level. The economic theory signals not only the growth-supportive role of exports, but also the possibility of the opposite direction of this relationship - from economic growth to exports development. Assuming the direction of impulses from economic growth to exports expansion, growth is based on an endogenous trend (Jung, and Marshall 1985). Such a direction of causality is indicated by Venables (1996), who claims that an increase in the scale of output leads to the transformations of exports. Helpman and Krugman (1985) argued that 
increasing output forces enterprises to overcome domestic market constraints in order to achieve economies of scale.

In the EU, a comprehensive analysis of interdependencies between trade in agri-food products and agricultural output was carried out by Strojny (2020). The author emphasised the diverse nature of relationships in respective countries.

\section{Conclusion}

In order to describe the relationships between the agricultural sector and foreign trade in goods produced on the basis of agricultural commodities for Poland, Spain and France, a VAR model reflecting short-term relationships was applied. For the Netherlands a VECM model characterising long-term relationships was used. The study leads to the following conclusions:

- For the major food exporters in the EU, two significant factors with certain interdependencies were identified: agricultural output and agri-food exports. Other trade measures were exogenous components of the estimated models. In the case of Spain, agri-food imports were also included in the VAR system.

- The high levels of output in the past have a negative impact, and exports have a positive impact on agricultural output.

- The causality test implies significant interdependencies between exports and output in Poland, Spain and France. In Spain and France, output is also determined by its own trend.

- In France, trends were identified with regard to exports being determined by the level of agricultural output.

- The impact of exports on agricultural output is of a short-term nature.

- Exports appear to be more exogenous than output. The lowest level of independence of agri-food exports is in the Netherlands.

\section{References}

Awokuse, T. (2005). Export-led growth and the Japanese economy: evidence from VAR and directed acyclic graphs. Applied Economics Letters, (12), 849-858.

Bahmani-Oskooee, M., and Economidou, C. (2009). Export led growth vs. growth led exports: LDCs Experience. The Journal of Developing Areas, 42(2), 179-212.

Baldwin, R., and Robert-Nicoud, F. (2006). Trade and growth with heterogeneous firms. Journal of International Economics, (74), 21-34.

Bossak, J., and Bieńkowski, W.(2004). Międzynarodowa zdolność konkurencyjna kraju iprzedsiębiorstw. Wyzwania dla Polski na progu XXI wieku. Warszawa: Wydawnictwo SGH.

Bosupeng, M. (2015). The export-led growth hypothesis: new evidence and implications. München: GRIN Verlag GmbH.

Bowler, I. R. (2014). The geography of agriculture in developed market economies. New York: Routledge.

Charemza, W., and Deadman D. (1997). Nowa ekonometria. Warszawa: PWE. 
Cherunilam, F. (2008). International economics. New Delhi: Tata McGraw-Hill.

Dinopoulos, E., and Segerstrom, P. (2006). North-south trade and economic growth (CEPR Discussion Papers No. 5887). Retrieved from https://www.google.com/url?sa=t\&rct=j\&q=\&esrc=s\&source= web\&cd=\&ved=2ahUKEwignufxuInrAhUNyaQKHeE-A7UQFjACegQIAxAB\&url=https\%3A $\% 2$ F\%2Frepec.cepr.org\%2Frepec\%2Fcpr\%2Fceprdp\%2FDP5887.pdf\&usg=AOvVaw1Oi 7LBACqRf-xQPeWbQeoZ

Eurostat. (n.d.). Retrieved June 12, 2020 from Eurostat database, https://ec.europa.eu/eurostat/data/ database

Feenstra, R. C. (1996). Trade and uneven growth. Journal of Development Economics, (49), 229-256.

Grossman, G. M., and Helpman, E. (1989). Endogenous product cycles (NBER Working Paper No. 2913). Retrieved from https://www.nber.org/papers/w2913

Gustafsson, P., and Segerstrom, P. (2010). Trade liberalization and productivity growth. Review of International Economics, 18(2), 207-228.

Helpman, E., and Krugman, P. R. (1985). Market structure and foreign trade. Increasing returns, imperfect competition, and international economy. Cambridge: The MIT Press.

Henriques, I., and Sadorsky, P. (1996). Export-led growth or growth-driven export? Canadian Journal of Economics, 29(3), 540-555.

Johansen, S. (1988). Statistical analysis of cointegration vectors. Journal of Economic Dynamics and Control, 12, 231-254.

Jung, S. W., and Marshall, P. J. (1985). Exports, growth and causality in developing countries. Journal of Development Economics, 18, 1-12.

Kusideł, E. (2000). Modele wektorowo-autoregresyjne VAR. Metodologia i zastosowania. Łódź: Absolwent.

Kwiatkowski, D., Phillips, P., Schmidt, P., and Shin, Y. (1992). Testing the null hypothesis of stationarity against the alternative of a unit root. Journal of Econometrics, 54, 159-178.

Lütkepohl, H. (1991). Introduction to multiple time series analysis. Berlin-Heidelberg: Springer-Verlag.

Misala, J. (2005). Wymiana międzynarodowa i gospodarka światowa. Teoria i mechanizmy funkcjonowania. Warszawa: Wydawnictwo SGH.

Nakonieczna-Kisiel, H. (1996). Handel zagraniczny jako bariera wzrostu gospodarczego. Geneza, konsekwencje, przezwyciężanie. Szczecin: Wydawnictwo Uniwersytetu Szczecińskiego.

Nowak, A., and Kozioł, W. (2011). Handel zagraniczny. Perspektywa europejska. Warszawa: Wydawnictwo Wydziału Zarządzania UW.

Osińska, M. (2006). Ekonometria finansowa. Warszawa: PWE.

Rivera-Batiz, L. A., and Romer P. (1991). International trade with endogenous technological change (NBER Working Paper No. 3594). Retrieved from https://www.nber.org/papers/w3594

Rosati, D. (1990). Polityka proeksportowa. Warszawa: PWN.

Rynarzewski, T., and Zielińska-Głębocka, A. (2006). Międzynarodowe stosunki gospodarcze. Teoria wymiany i polityki handlu międzynarodowego. Warszawa: Wydawnictwo Naukowe PWN.

Strojny, J. (2020). Wektorowe modele autoregresyjne $w$ analizie zależności między produkcja rolnq a wymianq zagranicznq towarów rolno-żywnościowych krajów Unii Europejskiej. Warszawa: Difin.

Unel, B. (2010). Technology diffusion through trade with heterogeneous firms. Review of International Economics, 18(3), 465-481.

Venables, A. (1996). Equilibrium locations of vertically linked industries. International Economic Review, 37, 341-359.

Yang, J. (2008). An analysis of so-called export-led growth (IMF Working Paper WP/08/220). Retrieved from https://www.imf.org/en/Publications/WP/Issues/2016/12/31/An-Analysis-of-So-Called-Exportled-Growth-22240 


\section{EKSPORT ROLNO-ŻYWNOŚCIOWY A PRODUKCJA ROLNICZA WYBRANYCH KRAJÓW UE}

Streszczenie: Badanie prowadzone w ujęciu sektorowym dla największych eksporterów żywności w UE koncentruje się na wpływie handlu zagranicznego produktami wytwarzanymi na bazie surowców rolnych na możliwości rozwoju produkcji rolniczej. Szczególnym przedmiotem zainteresowania są współzależności między produkcją a eksportem wskazanych towarów. Do opisu badanych związków zastosowano metodykę wektorowej autoregresji. Wyniki analiz wspierają hipotezę o stymulacyjnej roli eksportu w stosunku do produkcji, a w przypadku niektórych krajów identyfikują odwrotny kierunek relacji przyczynowej. Wpływ eksportu na produkcję rolniczą ma charakter krótkookresowy. Eksport jest czynnikiem bardziej egzogenicznym niż produkcja. Stopień egzogeniczności eksportu rolnożywnościowego jest najniższy w Holandii.

Słowa kluczowe: analiza kointegracyjna, modele VAR, produkcja rolna, eksport rolno-żywnościowy. 